\title{
Analysis of the direct and indirect costs of treatment of imported malaria in the Slovak Republic
}

\author{
Análise dos custos diretos e indiretos do tratamento da malária \\ importada na República Eslovaca
}

\author{
Viera Svihrova $^{1}$, Maria Szilagyiova ${ }^{2}$, Dusan Krkoska ${ }^{2}$, Katarina Simekova ${ }^{2}$, \\ Henrieta Hudeckova ${ }^{1}$ and Maria Avdicova ${ }^{3}$
}

\begin{abstract}
This study analyzed the approximate cost of treatment of patients hospitalized with a diagnosis of imported malaria in Slovakia. Between 2003 and 2007, 15 patients with imported malaria were hospitalized. The mean direct cost of the treatment was 970.75 euros and the mean indirect cost was 53.15 euros. For the patient with the highest cost of treatment, the use of mefloquine prophylaxis would have represented only $0.5 \%$ of the total direct cost of treating the disease. Despite the partial resistance of plasmodia, malaria chemoprophylaxis is unequivocally a cheaper choice than subsequent treatment of malaria.
\end{abstract}

Key-words: Imported malaria. Direct costs. Indirect costs. Slovak Republic.

\section{RESUMO}

Análise do custo aproximado do tratamento dos doentes hospitalizados na Eslováquia com malária importada. Entre 2003 a 2007, foram internados 15 doentes com malária importada. Os custos médios diretos do tratamento foram avaliados em 920,75 euros e indireto em 53,15 euros. No doente com o custo mais elevado de tratamento, a utilização da profilaxia com mefloquina representaria somente $0,5 \%$ do total dos custos diretos do tratamento da doença. Apesar da resistência parcial do plasmódio, a quimioprofilaxia da malária é inequivocamente uma opção mais econômica do que o tratamento posterior da malária.

Palavras-chaves: Malária importada. Custos diretos. Custos indiretos. República Eslovaca.

Malaria in the Slovak Republic currently ranks among the infectious diseases imported into this country. Among the patients affected by species of plasmodia, the most frequent cause of severe cases of malaria, with the highest cost of treatment, is Plasmodium falciparum.

Malaria chemoprophylaxis provides very effective protection against infection. It is important not only from the point of view of prevention of health problems, but also in relation to saving the financial costs of treating the disease. Among economically active individuals, it is also important for preventing the possible socioeconomic impact on the patient, his/her family and society.

1. Institute of Public Health, Jessenius Faculty of Medicine, Comenius University, Sklabinska 26, 03601 Martin, Slovak Republic. 2. Clinic of Infectology and Travel Medicine, Jessenius Faculty of Medicine, Comenius University, Kollarova 2, 03659 Martin, Slovak Republic. 3. Regional Institute of Public Health, Cesta k nemocnici 1, 97556 Banska Bystrica, Slovak Republic.

Financial support: This paper formed part of the grant VEGA No. 1/0038/08.

Address to: Dra. Viera Svihrova. Institute of Public Health, Jessenius Faculty of Medicine Comenius University, Sklabinska 26, 03753 Martin, Slovak Republic.

Tel: 00 421-43-41 32507

e-mail: svihrova@jfmed.uniba.sk

Received in 22/10/2008

Accepted in 21/07/2009
The goal of our paper was to calculate the direct and indirect costs of treatment of patients hospitalized with a diagnosis of malaria (ICD-10: B50-B54).

\section{MATERIAL AND METHODS}

An analysis on malaria patients hospitalized in the Slovak Republic from 2003 to 2007 was carried out. The data were obtained from the Epidemiological Information System (EPIS) of the Public Health Office of the Slovak Republic. From the data on hospitalized patients, we calculated and estimated the direct costs of health insurance companies for the treatment of all of the patients. The costs of hospitalization were obtained from health insurance companies and from the Healthcare Surveillance Authority. The exchange rate with the euro in 2007 was used for financial cost calculations. All costs involved in the hospitalization of patients, including possible transport between particular clinics, were considered in calculating the direct costs.

The indirect costs involved costs paid by the employers in the form of compensation for lost income, the health fund costs of the Social Insurance Company and the health benefits and production losses due to reduction of the gross domestic product (GDP) during the worker's incapacitation. For adult patients during the 
first 10 days of incapacitation, income compensation is paid by the employer: for the first three days, it is $25 \%$ of the calculated daily basis and, thereafter, it is $55 \%^{3}$. The lowest possible calculated basis is a daily basis defined as one thirtieth of the minimum salary for workers paid by monthly salary, from the day on which the valid claim for compensation started ${ }^{2}$. In calculating the costs, the basis that we took was the minimum salary in 2007 , which was 224.98 euros per month. The minimum hourly wage was 1.29 euros. The data were processed using the SPSS software, Windows edition, version 11.0. All group data were expressed as means and ranges.

\section{RESULTS}

From 2003 to 2007 in the Slovak Republic, 17 cases of imported malaria were identified from EPIS. In two cases, the disease did not require hospitalization and malaria chemoprophylaxis alone was used. The remaining 15 patients were hospitalized due to their diagnosis of imported malaria. These patients' mean age was 32 years, with a range from 20 to 55 years (Table 1). The length of their hospitalization was $4-26$ days, with mean length of 11 days. All the above patients had visited endemic malaria areas; only six of them ( $40 \%)$ were using malaria chemoprophylaxis before the travel and during their sojourn in endemic areas. Most (13 cases) infections were acquired in Africa. The infection agents were Plasmodium vivax in six cases and Plasmodium falciparum in seven cases. Two patients had dual infection. Twelve patients did not present complications, but complications were present in the other three cases (two cases of Plasmodium falciparum and one case of dual infection). Thirteen patients were admitted to the Infectology Clinic. Because of the clinical condition of the other two patients, they were transferred from the Infectology and Travel Medicine Clinic to the Anesthesiology and Intensive Care Clinic and to the Internal Medicine Clinic.

From the calculation of the costs for completed hospitalization, from the point of view of compensation from the health insurance company, the direct cost of treating these 15 patients during their hospitalization reached the total of 11,845.21 euros. The mean direct cost per patient was 970.75 euros (Table 2).

The indirect costs involved compensation for loss of income, from the employer for the first 10 days of incapacitation, and compensation from the Social Insurance Company for subsequent days. The salary loss at the minimal monthly salary rate was the sum of 60.37 euros for 11 days of incapacitation, which meant that the income decreased by $53 \%$.

In the Slovak Republic, according to the current regulations of the Ministry of Health ${ }^{8}$, drugs for prevention or treatment of malaria are registered in the list of drugs that are fully or partially covered by public health insurance. The mean cost of two months of individual prevention by means of malaria chemoprophylaxis is, statistically, significantly lower than the direct cost of malaria treatment. When mefloquine is used, as recommended by the World Health Organization for endemic malaria areas ${ }^{12}$, it represents $5.7 \%$ of the total cost of treatment for patients with the lowest compensation from the insurance company. The cost

TABLE 1

\begin{tabular}{|c|c|c|c|c|c|c|}
\hline Case & Age & Gender & $\begin{array}{c}\text { Place } \\
\text { of infection }\end{array}$ & $\begin{array}{c}\text { Plasmodium } \\
\text { species }\end{array}$ & $\begin{array}{c}\text { Length of inpatient } \\
\text { stay (days) }\end{array}$ & $\begin{array}{l}\text { Using of malaria } \\
\text { chemoprophylaxis }\end{array}$ \\
\hline \multicolumn{7}{|l|}{2003} \\
\hline 1 & 25 & male & Chad & falciparum & 5 & no \\
\hline 2 & 42 & male & Myanmar & vivax, falciparum & 20 & no \\
\hline \multicolumn{7}{|l|}{2004} \\
\hline 3 & 26 & male & Eritrea & vivax & 11 & yes \\
\hline 4 & 24 & male & Eritrea & vivax & 10 & yes \\
\hline 5 & 22 & male & Eritrea & vivax & 10 & yes \\
\hline 6 & 35 & male & Eritrea & vivax & 6 & yes \\
\hline \multicolumn{7}{|l|}{2005} \\
\hline 7 & 32 & male & Cameroon & falciparum & 5 & yes \\
\hline \multicolumn{7}{|l|}{2006} \\
\hline 8 & 55 & female & Uganda & vivax & 10 & no \\
\hline 9 & 27 & male & Ivory Coast & vivax & 10 & yes \\
\hline 10 & 34 & male & Equatorial Guinea & falciparum & 15 & no \\
\hline 11 & 35 & male & Benin & falciparum & 26 & no \\
\hline 12 & 20 & male & Benin & falciparum & 14 & no \\
\hline 13 & 28 & male & Ecuador & vivax, falciparum & 9 & no \\
\hline 14 & 41 & male & Angola & falciparum & 10 & no \\
\hline \multicolumn{7}{|l|}{2007} \\
\hline 15 & 32 & male & Equatorial Guinea & falciparum & 4 & no \\
\hline
\end{tabular}


TABLE 2

Comparison of direct and indirect costs of treatment and cost of malaria chemoprophylaxis, in euros.

\begin{tabular}{|c|c|c|c|}
\hline & Mean & $\begin{array}{c}\text { Lowest costs: } \\
4 \text { days of hospitalization }\end{array}$ & $\begin{array}{c}\text { Highest costs: } \\
26 \text { days of hospitalization }\end{array}$ \\
\hline \multicolumn{4}{|l|}{ Direct costs } \\
\hline cost of hospitalization & 789.68 & 376.87 & $3,472.96$ \\
\hline cost of laboratory and imaging examinations & 181.07 & 51.86 & $1,175.63$ \\
\hline total cost & 970.75 & 428.73 & $4,648.59$ \\
\hline \multicolumn{4}{|l|}{ Indirect costs } \\
\hline compensation for income by employer and by social insurance & 53.15 & 13.42 & 138.29 \\
\hline Total direct and indirect costs & $1,023.90$ & 442.15 & $4,786.88$ \\
\hline$\%$ of chemoprophylaxis from direct and indirect costs* & 2.5 & 5.7 & 0.5 \\
\hline
\end{tabular}

*cost of malaria chemoprophylaxis for two months (mefloquine) in the Slovak Republic is 25.14 euros.

of mefloquine chemoprophylaxis (25.14 euros) is lower than the loss of income due to four days of incapacitation (27.86 euros). In the case of the patient with the highest costs, the use of chemoprophylaxis represented only $0.5 \%$ of the total direct cost of treatment.

\section{DISCUSSION}

The most important endemic areas for malaria are in SubSaharan Africa, South-West Pacific, South-East Asia and rain forests of South America ${ }^{14}$. According to the Centers for Disease Control and Prevention, the annual incidence of malaria around the world accounts for 350 - 500 million cases, with one million deaths ${ }^{1}$. In the Slovak Republic, according to EPIS, there were 48 reported cases of imported malaria between 1997 and 2007.

According to many authors, malaria causes a GDP loss of as much as $0.6 \%-1.3 \%$ in countries with high malaria incidence ${ }^{710}$. Among these countries, the cost of treating one case of malaria in Ethiopia is 1.44 USD $^{5}$, Sudan 6.3 USD $^{9}$ and Burkina Faso 8.0 USD $^{6}$. The average indirect costs for a fully cured patient were 4.08 USD in Ethiopia, 3.2 USD in Sudan and 3.7 USD in Burkina Faso.

In the accessible literature, we did not find any comprehensive calculations of the direct and indirect costs of imported malaria in high-income countries. The cases of fifteen soldiers in the British army who required intensive hospital therapy because of malaria infection was described. Out of 24,600 British troops stationed in Germany, approximately 800 were occupationally exposed to malaria during 2001, and 800 during 2002. There were three imported malaria cases in British soldiers during 2001 and 12 during 2002. Two soldiers (one with Plasmodium vivax, the other with Plasmodium falciparum infection) required intensive hospital therapy. The median length of hospital inpatient stay was seven days (for Plasmodium vivax infection) and 8.5 days (for Plasmodium falciparum). The direct treatment costs of the hospitalizations totaled 27,760 euros. All the soldiers in that study were prescribed mefloquine for malaria chemoprophylaxis ${ }^{4}$.

In our series of patients, the direct cost of malaria treatment involving the hospitalization along with the costs of laboratory and imaging examinations was 970.75 euros per patient. It did not include the costs of the subsequent outpatient checkups and follow-up examinations after the hospitalization. The indirect cost consisted of compensation for lost income paid by the employer and the insurance paid by the Social Insurance Company and, for the 11 days of incapacitation, this amounted to 53.15 euros. Furthermore, the other indirect costs (lost salaries, decreased production and lessened GDP) were non-negligible. The loss of income in 2007 was 60.37 euros (27.86 - 130.03 euros) and the loss of productivity in 2007, in terms of the current GDP/person/ day, was 306.13 euros (111.32 - 723.58 euros) for 11 days of incapacitation/person/day ${ }^{11}$.

It is generally known that chemoprophylaxis cannot provide absolute protection against malaria because of the resistance of plasmodia to antimalarial drugs ${ }^{13}$. However, chemoprophylaxis along with non-pharmacological prevention against mosquito bites (white clothes covering the entire body, mosquito nets and repellents) significantly decreases the risks of infection and alleviates the course of the disease ${ }^{12}$. Before traveling to malarial regions, it is essential to have a medical checkup from a specialist and to obtain expert advice on malaria chemoprophylaxis.

Costs of malaria treatment and malaria chemoprophylaxis must be taken into account from the point of view of the individual at risk, with regard to patients' quality of life or even the safety of their lives. Despite the partial resistance of plasmodia, malaria chemoprophylaxis is unequivocally a cheaper choice than subsequent treatment of malaria.

\section{ACKNOWLEDGEMENTS}

We are grateful to the insurance companies Dôvera a.s., SZP a.s. and Union ZP a.s. for their cooperation, particularly for allowing access to data on the costs of medical care provided. The authors thank Mr. Frederico Goncalves for technical assistance.

\section{REFERENCES}

1. Centers for Disease Control and Prevention. Malaria facts. 2007. Accessed on http://www.cdc.gov/malaria. cited: 24 July, 2008.

2. Collection of Acts Slovak Republic. Act No. 462/2003 Coll.: 3704-3708, 2003.

3. Collection of Acts Slovak Republic. Act No. 461/2003 Coll.: 1386-1545, 2008. 
4. Croft AM, Winfield CR, Horsfall M, Quarrell MA. Direct health costs of occupationally acquired malaria in a military population in Europe. Occupational Medicine 55: 128-130, 2005.

5. Deressa W, Hailemariam D, Ali A. Economic costs of epidemic malaria to households in rural Ethiopia. Tropical Medicine and International Health 12: 1148-1156, 2007

6. Guiguemde TR, Coulibaly N, Coulibaly SO, Ouedraogo JB, Gbary AR. A precise method for estimating the economic costs of malaria: Application of the method in a rural area in Burkina Faso (West Africa). Tropical Medicine and International Health 2: 646-653, 1997.

7. Hollyman S, Gathany J, Buj V. 10 Facts on Malaria. World Health Organization. 2007. Accessed on http://www.who.int/features/factfiles/malaria. cited: 24 July, 2008.

8. Ministry of Health Slovak Republic. Bulletin of the Ministry of Health Slovak Republic: Regulation of the Ministry of Health Slovak Republic No. OPL020813444/2008-OL. Obzor, Bratislava, 2008.
9. Mustafa MH, Babiker MA. Economic costs of malaria on households during a transmission season in Khartoum State, Sudan. Eastern Mediterranean Health Journal 13: 1298-1307, 2007.

10. Shepard DS, Ettling MB, Brinkmann U, Sauerborn R. The Economic Costs of Malaria in Africa. Tropical Medicine and Parasitology 42: 199-203, 1991.

11. Statistical Office of the Slovak Republic. Indicators of Economic Development of the SR. 2008. Accessed on http://portal.statistics.sk/showdoc.do?docid=19. Cited: 24 July, 2008

12. Wilder-Smith A. International Travel and Health 2008. World Health Organization, Geneva, 2008.

13. World Health Organization. Guidelines for the treatment of malaria. World Health Organization, Geneva, 2006.

14. World Health Organisation. Global Malaria Control and Elimination: Report of a Technical Review. World Health Organization, Geneva, 2008 